\title{
Identification of Ectomycorrhizal Fungi from Pinus densiflora Seedlings at an Abandoned Coal Mining Spoils
}

\author{
Park, Sang-Hyeon, Hyeon-Suk Jeong, Yoo-Mee Lee, Ahn-Heum Eom* and Chang-Seok Lee ${ }^{1}$ \\ Department of Biology Education, Korea National University of Education, Cheongwon 363-791, Korea \\ ${ }^{\prime}$ Faculty of Environment and Life Sciences, Seoul Women's University, Seoul 139-774, Korea
}

\begin{abstract}
This study was conducted to identify native ectomycorrhizal (ECM) fungi colonizing Pinus densiflora for revegetation of abandoned coal mines in Korea. Seedlings of $P$. densiflora growing on coal mining spoils of a study site in Samcheok were collected. ECM roots were observed under stereomicroscope and their DNA were extracted from each root tip for a seedling for molecular identification. A PCR primer pair specific to fungi, ITS1F and ITS4, was used to amplify fungal DNA. Restriction enzymes, Alul and Hinfl were used for restriction fragment length polymorphism (RFLP). Combined with RFLP profiles and sequence analysis, total twenty one taxa were identified from the ECM root tips. Basidiomycetous fungi including Thelephoraceae, Pezizales, Laccaria, Pisolithus and Ascomycetous fungi including ericoid mycorrhizal fungi were identified from this study. Results showed that the most frequently found in the study sites was a species in Thelephoraceae. A possible use of ECM fungi identified in this study for the revegetation of abandoned coal mines with $P$. densiffora was discussed.
\end{abstract}

Key words: Ectomycorrhiza, Ericoid mycorrhiza, ITS, Mine spoils, Revegetation, RFLP

\section{INTRODUCTION}

Mycorrhizal symbioses which are relationship between plant roots and fungi provide plants with increase access to resources, such as water, nitrogen and phosphorus (Smith and Read 1997). They also protect plant from pathogens and from extremes soil chemical conditions, such as high $\mathrm{pH}$ and from heavy metal contamination and facilitate establishment of pioneer plants in harsh environments.

All coal mining activities have been progressed by deep mining in Korea where all coal deposits are underlain in deep underground. Coal mining activity usually, therefore, leads to very much debris. Such coal mining debris has been piled up on the mountain or reclaimed in the mountain valley. Therefore, acid mine drainage, barren unvegetated mined area, and steep unstable slopes of mining spoils were frequently left behind after mining. And even when these areas are vegetated, exotic or non-local species were usually applied for rehabilitation of those areas. In consequence, most rehabilitated mine areas appear in an ecological space unfamiliar with surrounding nature. In fact, deep mining debris is not the soil yet as itself because there is no organic matter. Therefore, ecosystem development in progress here is the same as a primary succession. Succession is progressed by reaction of plants growing in a given area, facilitation particularly in primary succession. Facilitation is an influence that promotes species compositional change to the next stage in successional context (Connell and Slatyer 1977, Van Andel et al. 1993). Most plants modify their immediate environment in some way that can impact establishment and growth of both other species and other individuals of the same species. Differential species responses to these environmental changes can drive succession (Wright and Muller-Dombois 1988). Presence of mycorrhizae can facilitate establishment and growth of plants by stabilizing a site and consequently facilitate succession (Allen et al. 1999). Rehabilitation is closely linked to succession theory. In reality, successional process or ecosystem development provide trajectory of rehabilitation (Dobson et al. 1997, Zedler and Callaway 1999). But natural recovery such as succession is too slow. So, rehabilitation is a process, which facilitates the successional process by human intervening. In this respect, role of mycorrhizae is expected in rehabilitation project of coal mining spoils.

The abandoned coal mine spoils have been various environmental problems including a source of heavy metal contamination of soil and water. These sites are extreme for plant growth and it is difficult to revegetate these sites due to the low nutrients, toxic materials and high temperature. Under such conditions, mycorrhizal symbioses play an important role for plant establishment, growth and nutrition (Malajczuk et al. 1994, Pfleger et al. 1994, Smith and Read 1997). Marx et al. (1982) demonstrated that inoculation of

* Corresponding author; Phone: +82-43-230-3767, e-mail: eomah@knue.ac.kr 
pine seedlings with ectomycorrhizal (ECM) fungi improved seedling growth and establishment in these sites. An ECM fungal species Pisolithus tinctorius has been widely used for revegetation of mine land because it showed high success rates at field trials, possibility of commercial production of large amounts of inoculum and a broad host range (Ruehle and Marx 1979). However, not all species of ECM fungi protect their hosts from toxic heavy metals and other stresses. The specificity between host and ECM fungi is thought to influence ecosystem function and to benefit both plant and fungal partners (Molina and Trappe 1982). Even within a species of ECM fungi, native isolates from polluted sites were more efficient at protecting plants from toxic metals than isolates from non-polluted sites (Adriaensen et al. 2004, Adriaensen et al. 2005). Also, competition with native fungi in these sties may influence success of pre-inoculated non-native ECM fungi (Villeneuve et al. 1991).

Much of our knowledge about community composition of ECM fungi has been based on the observations of fungal sporocarps. However, sporocarp composition does not usually reflect active fungal composition in ECM roots (Gardes and Bruns 1996, Jonsson et al. 1999a, van der Heijden et al. 1999). Therefore, morphological classification of ECM root tips has been used to determine the fungi that are actively associated with plant roots (Agerer 1987-1998, Goodman et al. 1996-2000). However, morphological classification of the root tips did not provide accurate identification of ECM fungi and was not consistent with results of molecular studies using ECM root tip (Jonsson et al. 1999b, Sakakibara et al. 2002). Recent advances of molecular technique have been applied to the studies of ECM fungal diversity using restriction fragment length polymorphisms (RFLP) and DNA sequencing of the internal transcribed spacer (ITS) region of nuclear rDNA extracted from the ECM root tips (Egger 1995, Gardes and Bruns 1996, Horton and Bruns 2001). Using molecular methods, it has been possible to identify fungal species from single ECM root tips. The molecular methods are widely used in studying ECM community and new methods are being actively developed. The object of this study was to investigate composition of native ECM fungi colonizing roots of seedlings of Pinus densiflora at a site of abandoned coal mines in Korea. This information will be useful for future re-vegetation effort using ECM fungi as inoculum sources of pine seedlings in the study site. We used PCR-RFLP and sequence analysis for identification of ECM fungi from the ECM root tips and it will provide clear insight to below ground $\mathrm{ECM}$ composition in mine spoil sites.

\section{MATERIALS AND METHODS}

\section{Study Site}

Study sites are located on Neukgu-ri, Dogye-eup of Samcheok in Gangwon Province, central eastern Korea $\left(37^{\circ} 15^{\prime} 14.32^{\prime \prime} \mathrm{N}, 129^{\circ}\right.$ $02^{\prime} 38.44^{\prime \prime}$ W). A mining company of Samma Tajeong had managed this site during mining activity. After abandonment of mining activity, the company piled up coal mining debris in terrace type to ensure physical stability. After then, they covered the terraces with forest soil and introduced plants following the typical rehabilitation procedure of coal mining spoils in Korea. They usually introduced black locust in the past but birch in these days. At present, most forest soil disappeared by erosion and we hardly find black locust as well in this site because most of them were died. Birches, which were introduced by the second rehabilitation project, grow sparsely and pine (Pinus densiflora) and several grasses were introduced naturally and fill in the spaces among them. The coal mining spoils of the study sites are sandy roams and contained 0.97 $\mathrm{mg} \mathrm{kg}{ }^{-1}$ available phosphorus, $0.27 \%$ of total nitrogen, $5 \%$ organic matter, $4.55 \mathrm{cmol}^{+} \mathrm{kg}^{-1}$ exchangeable cations (CEC) and had a $\mathrm{pH}$ of 4.3 .

\section{Root Sampling}

Thirty seedlings of $P$. densiflora were randomly collected from the study site. Seedlings with root were transported to the laboratory, and stored at $4^{\circ} \mathrm{C}$ until they were processed. Roots were washed gently and ECM root tips were observed under stereomicroscope and were classified according to morphological characteristics including color, branching pattern, rhizomorphs, mantle surface of the tips. The most dominant morphotype among ECM root tip for a seedling was selected for molecular identification.

\section{PCR-RFLP and Sequence Analysis}

A root tip was homogenized in a PCR tube using micropestle and DNA was extracted from ECM root tips using DNeasy Plant mini kit (Qiagen Science, USA). The partial internal transcribed spacer (ITS) of rDNA was amplified using the fungal specific primer pair ITS1F and ITS4 (Gardes and Bruns 1993). Thermocycling for PCR was conducted as follows: $94^{\circ} \mathrm{C}$ for $3 \mathrm{~min}$ for 1 cycle, $94^{\circ} \mathrm{C}$ for $1 \mathrm{~min}, 55^{\circ} \mathrm{C}$ for $1 \mathrm{~min}, 72^{\circ} \mathrm{C}$ for $1 \mathrm{~min}$ for $35 \mathrm{cycle}, 72^{\circ} \mathrm{C}$ for $7 \mathrm{~min}$ for 1 cycle. One sample of root tips did not yield PCR product, considering not viable and total 29 DNA products from root tips were used for molecular analysis. The amplified ITS region was characterized by restriction fragment length polymorphism (RFLP) using restriction enzymes Hinfl and AluI. Fragment lengths were quantified and compared on $2 \%$ agarose gel. Nucleotide sequences for each RFLP pattern were determined using $A B I$ PRISM 377 automated sequencer (Perkin-Elmer, USA). A sequence similarity search of the National Center for Biotechnology Information (NCBI) database was conducted using Basic Local Alignment Search Tool (BLAST) algorithm. The sequences were aligned with 
CLUSTAL X 1.81 (Thompson et al. 1994) and used for multiple alignment and neighbor-joining phylogeny (Saitou and Nei 1987), using Rhizophus stolonifer as an outgroup.

\section{RESULTS AND DISCUSSION}

The thirty ECM root tips were collected from roots of 30 pine seedlings in the study site, an abandoned coal mine. DNA were extracted and amplified with fungal specific primers from 29 tips and one tip did not provide PCR product. Twenty two groups of restriction fragment patterns were distinguished with two restriction enzymes, AluI and HinfI (Table 1). Sequence analysis showed that RFLP analysis with two restriction enzymes $A l u I$ and $H i n f I$ used in this study did not clearly separate fungi belonging to Ascomycetes

Table 1. Restriction fragment patterns of DNA extracted from the 29 root tips of ECM fungal species from seedlings of Pinus densiflora collected in abandoned mine spoil

\begin{tabular}{|c|c|c|c|c|c|c|c|c|c|c|}
\hline \multirow{2}{*}{$\begin{array}{l}\text { RFLP } \\
\text { Group }\end{array}$} & \multirow{2}{*}{$\begin{array}{l}\text { Root } \\
\text { sample }\end{array}$} & \multicolumn{9}{|c|}{ Restriction enzymes } \\
\hline & & $A l u \mathrm{I}$ & & & & & Hinfl & & & \\
\hline 1 & ST4 & 620 & 75 & & & & 380 & 200 & 110 & \\
\hline 2 & ST5 & 260 & 220 & 200 & & & 335 & 200 & 115 & \\
\hline \multirow[t]{2}{*}{3} & R17 & 375 & 245 & 80 & & & 210 & 200 & 145 & 110 \\
\hline & $\mathrm{R} 21$ & 375 & 245 & 80 & & & 215 & 200 & 145 & 110 \\
\hline 4 & $\mathrm{R} 22$ & 370 & 130 & 90 & & & 370 & 320 & & \\
\hline 5 & ST2 & 390 & 160 & 75 & & & 375 & 315 & & \\
\hline \multirow[t]{3}{*}{6} & ST3 & 375 & 240 & 80 & & & 365 & 320 & & \\
\hline & ST7 & 375 & 235 & 80 & & & 365 & 325 & & \\
\hline & ST10 & 375 & 250 & 75 & & & 363 & 330 & & \\
\hline 7 & R7 & 485 & 195 & & & & 363 & 310 & & \\
\hline 8 & ST9 & 320 & 218 & 175 & & & 390 & 315 & & \\
\hline 9 & ST6 & 260 & 180 & 100 & 90 & 55 & 285 & 200 & 145 & 55 \\
\hline \multirow[t]{2}{*}{10} & CT5 & 445 & 125 & 70 & 55 & & 340 & 200 & 145 & \\
\hline & CT4 & 445 & 100 & 90 & 55 & & 340 & 200 & 155 & \\
\hline \multirow[t]{2}{*}{11} & ST12 & 440 & 145 & 70 & & & 335 & 200 & 100 & \\
\hline & $\mathrm{CT} 7$ & 440 & 145 & 70 & & & 335 & 200 & 100 & \\
\hline 12 & R19 & 570 & 60 & & & & 310 & 230 & 100 & \\
\hline 13 & CT3 & 480 & 110 & 100 & & & 340 & 245 & 100 & \\
\hline \multirow[t]{2}{*}{14} & ST11 & 590 & 70 & & & & 340 & 240 & 100 & \\
\hline & CT6 & 590 & 70 & & & & 340 & 245 & 100 & \\
\hline 15 & ST1 & 645 & & & & & 310 & 168 & 160 & \\
\hline 16 & LT2 & 475 & 145 & & & & 300 & 180 & 130 & \\
\hline \multirow[t]{2}{*}{17} & LT3 & 610 & & & & & 305 & 305 & & \\
\hline & ST8 & 605 & & & & & 300 & 300 & & \\
\hline 18 & LT4 & 470 & 145 & & & & 305 & 300 & & \\
\hline 19 & ST13 & 385 & 225 & & & & 305 & 300 & & \\
\hline 20 & CT10 & 690 & & & & & 380 & 300 & & \\
\hline 21 & CT2 & 660 & & & & & 335 & 320 & & \\
\hline 22 & CT1 & 560 & 125 & & & & 435 & 195 & & \\
\hline
\end{tabular}


(RFLP groups 15 22, Table 1). The results suggest use of more restriction enzymes for further separation of this group of fungi.

Twenty nine sequences were compared with sequences in Genbank database at NCBI for molecular identification using BAST analysis (Table 2). The closest sequences to ones from this study were obtained at GenBank. A neighbor-joining phylogram was obtained using 19 the close sequences and 29 sequences from this study. The groups from the phylogram were consistent with RFLP groups with a few exceptions (Fig. 1). Using both groups from RFLP patterns and the phylogram, twenty taxa of ECM fungi were

Table 2. Best BLAST matches to known species of sequences of fungi from ectomycorrhizal roots tip of Pinus densiflora seedlings collected in a coal mine spoil

\begin{tabular}{|c|c|c|c|c|}
\hline \multirow{2}{*}{ Identity } & \multirow{2}{*}{$\begin{array}{c}\text { Root } \\
\text { sampels }\end{array}$} & \multicolumn{3}{|c|}{ Best BLAST matches to known species } \\
\hline & & Fungal Species & Accession number & Sequence similarity $(\%)$ \\
\hline Polyporales sp. & ST4 & Uncultured ECM & DQ377437 & $497 / 513(96 \%)$ \\
\hline Pisolithus sp. & ST5 & Pisolithus sp. & AF270774 & $172 / 173(99 \%)$ \\
\hline \multirow[t]{2}{*}{ Suillus bovinus } & $\mathrm{R} 17$ & Suillus bovinus & $\mathrm{AB} 036902$ & $666 / 671(99 \%)$ \\
\hline & $\mathrm{R} 21$ & Suillus bovinus & $\mathrm{AB} 036902$ & $665 / 671(99 \%)$ \\
\hline \multirow[t]{2}{*}{ Cortinarius sp. } & $\mathrm{R} 22$ & Cortinarius callisteus & DQ097876 & $581 / 591(98 \%)$ \\
\hline & ST2 & Cortinarius callisteus & DQ097876 & $451 / 458(98 \%)$ \\
\hline \multirow[t]{3}{*}{ Laccaria amethystine } & ST3 & Laccaria amethystine & $\mathrm{AB} 211270$ & $444 / 446(99 \%)$ \\
\hline & ST7 & Laccaria amethystine & $\mathrm{AB} 211270$ & $249 / 277(89 \%)$ \\
\hline & ST 10 & Laccaria amethystine & $\mathrm{AB} 211270$ & $434 / 435(99 \%)$ \\
\hline Inocybe spl & R7 & Uncultured soil fungus & AY704731 & $205 / 206(99 \%)$ \\
\hline Inocybe $\mathrm{sp} 2$ & ST9 & Inocybe lanuginosa & DQ367905 & $648 / 709(91 \%)$ \\
\hline Tomentella spl. & ST6 & Uncultured ECM & AY748885 & $660 / 672(98 \%)$ \\
\hline Tomentella $\mathrm{sp} 2$. & CT5 & Thelephoraceae sp. & AY751561 & $624 / 648(96 \%)$ \\
\hline . & CT4 & Thelephoraceous ECM & AF430259 & $620 / 658(94 \%)$ \\
\hline \multirow[t]{2}{*}{ Thelephora $\mathrm{spl}$} & ST12 & Uncultured ECM & AY 822747 & $660 / 671(98 \%)$ \\
\hline & $\mathrm{CT} 7$ & Uncultured ECM & AY822747 & $660 / 671(98 \%)$ \\
\hline Thelephora $\mathrm{sp} 2$ & $\mathrm{R} 19$ & Uncultured ECM & AJ633596 & $631 / 640(98 \%)$ \\
\hline Thelephora $\mathrm{sp} 3$ & $\mathrm{CT} 3$ & Uncultured ECM & AY 822747 & $658 / 667(98 \%)$ \\
\hline \multirow[t]{2}{*}{ Thelephora sp4 } & ST11 & Uncultured ECM & AY 822747 & $660 / 666(99 \%)$ \\
\hline & CT6 & Uncultured ECM & AY 822747 & $663 / 670(98 \%)$ \\
\hline Wilcoxina mikolae & ST1 & Wilcoxina mikolae & DQ069000 & $585 / 589(99 \%)$ \\
\hline Oidiodendron maius & $\mathrm{LT} 2$ & Oidiodendron maius & AF062798 & $517 / 519(99 \%)$ \\
\hline \multirow[t]{2}{*}{ Leptodontium sp. } & LT3 & Mycorrhizal ascomycete & $\mathrm{AB} 089660$ & $477 / 486(98 \%)$ \\
\hline & LT4 & Mycorrhizal ascomycete & AB 089660 & $520 / 522(99 \%)$ \\
\hline Helotiaceae sp. & ST13 & Calycina herbarum & AY348594 & $446 / 476(93 \%)$ \\
\hline \multirow[t]{2}{*}{ Hymenoscyphus sp. } & ST8 & Hymenoscyphus ericae & AY394907 & $537 / 545(98 \%)$ \\
\hline & СТ10 & Hymenoscyphus ericae & AY394907 & $534 / 543(98 \%)$ \\
\hline Helvellaceae sp. & $\mathrm{CT} 2$ & Talaromyces helicus & AF033396 & $538 / 559(96 \%)$ \\
\hline Pezizales sp. & CT1 & Uncultured ECM & AY 684066 & $611 / 673(90 \%)$ \\
\hline
\end{tabular}




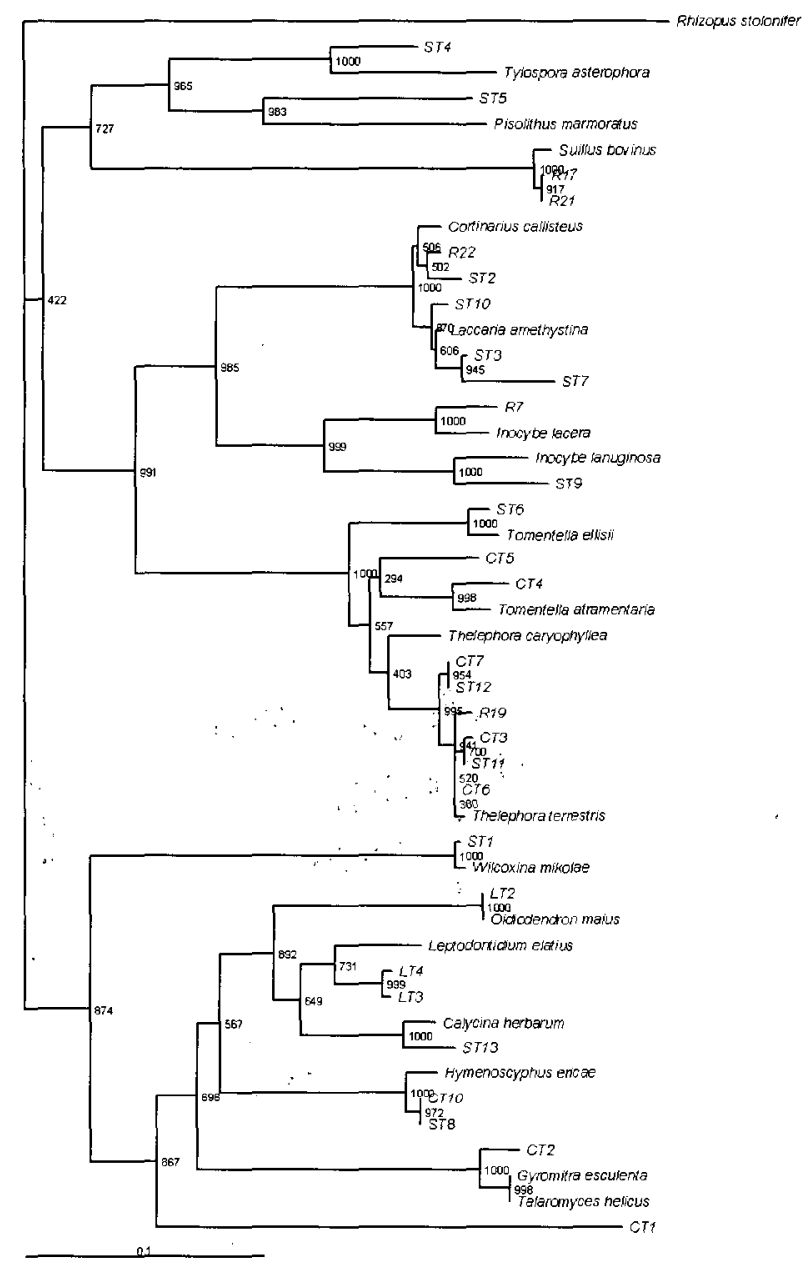

Fig. 1. Neighbor joining tree illustrating the taxonomic affinities of the sequences obtained from the ECM fungi. Rhizopus stolonifer was as an outgroup.

identified (Table 2). Taxonomic names were assigned to species based on the names of best matched sequences on the GenBank. Only sequences with more than $99 \%$ nucleotide sequences provided same name as GenBank sequences and only names for genus, family or order were used for the other sequences. The high species numbers of ECM fungi in this study are typical of the ECM fungal communities in other studies (Allen et al. 1995, Bruns 1995), although it is difficult to directly compare species numbers due to different sampling methods in sampling and study size.

Both Ascomycetous and Basidiomycetous fungi were found from the ECM root tips in the study site. Thirteen taxa were species in Basidiomycetes and 7 taxa were in Ascomycetes. Basidiomycetous fungi were found in the roots of twenty of 29 pine seedlings, while Ascomycetous fungi were found in only nine seedlings. Thelephoroid fungi were the most frequently found ECM fungi in the study site. Total six fungal groups in two genera Thelephora and Tomen- tella were appeared in 9 roots of 29 seedlings. Root tips, ST12, CT7, CT3, ST11 and CT6 were the best matched with a same sequence "uncultured ECM (AY822747)" in GenBank using BLAST search. Also, these tips were grouped within a clade with Thelephora terrestris in the phylogram (Fig. 1). However, in RFLP pattern, these tips were divided into 3 different groups (Table 1) and the fungal group names for these root tips were assigned as Thelephora sp1, $T$. sp3 and T. sp4, based on the RFLP groups (Table 2). Laccaria amethystine also appeared in three seedlings and Pisolithus sp. might be $P$. tinctorius because the sequences showed $98 \%$ nucleotide similarity with $P$. tinctorius (AF374717) and sporocarps of $P$. tinctorius were frequently found in a pine forest upside the study sties. P. tinctorius was a typical ECM fungal species in these harsh environments and one of the ECM fungal inoculum which has been widely used for revegetation of mine land and other disturbed land. The sequences of fungal taxa identified as Thelephora sp., Inocybe spl, Leptodontium and Pezizales sp. in this study were the best matches with the sequences of unknown or uncultured ECM fungi (Table 2). These sequences were not reported in the GenBank and these fungi may not be culturalble.

The ECM fungi in Thelephoraceae, Laccaria, Inocybe and Pisolithus were the dominant species found in the study site and these fungal species are known as "early stage" species of ECM fungal succession, which were colonized on young roots and demand small amount of carbon from their hosts and require low concentration of mineral nutrients (Colpaert et al. 1996). The early colonizing species typically colonize by spores and common ECM mycobionts with seedlings in disturbed area including mine spoils. These early stage ECM fungi might be important roles in establishment and growth of hosts in stressed sites and forest succession. The "late stage" or "mixed stage" species of ECM fungi, Suillus and Cortinarius, were also found in the study sites, which require greater amount of carbon and nutrients and colonize by hyphae (Colpaert et al. 1996). These species might be replacing early stage ECM fungi. However, because many factors influence changes in species composition of fungi during the ECM succession, early and late stage classification may not be appropriate for the description of ECM succession (Keizer and Arnolds 1994).

Seven fungal taxa of Ascomycetes were found in this study. While Wilcoxina mikolae, Pezizaceae and Helvellaceous fungi have been known as ECM fungi among these fungi, the other four fungal taxa, Leptodontium sp. Helotiaceaous sp. Hymenoscyphus sp. and Oidiodendron maius, were known to be ericoid mycorrhizal (ERM) fungi. It has been hypothesized that ERM and ECM plant share common mycorrhizal partners and it was supported by observation identical genotypes in roots of coexisting ERM and ECM hosts (Bergero et al. 2000). Also, Villarreal-Ruiz et al.(2004) demonstrated 
that ERM fungi Hymenoscyphus ericae simultaneously form both ECM and ERM in roots of Pinus and Vaccinum. In study site, Rhododendron species were distributed with pine seedlings suggesting common mycorrhizal partners with both pine and ericaceous hosts. This group of fungi may play an important role in the stressed sites.

Natural organisms surviving in heavy metal contaminated ecosystems are often subjected to selective pressures for increased resistance to the metals. In the present study we describe the ECM fungi that colonized roots of pine seedlings collected in a coal mine spoil in Korea. These fungi might have developed adaptive tolerance to harsh environment and were able to protect pine seedlings against these environmental stresses. Such adapted ECM fungi-host combination might be suitable for effective revegetation of abandoned coal mines. In further study, these native ECM fungi isolated from the root or sporocarps will be inoculated to the plants to test plant growth in these conditions and this information will be useful for future revegetation effort in the study site.

\section{ACKNOWLEDGEMENTS}

This study was supported by Korean Ministry of Environment as "The Eco-technopia 21 project titled in" Ecological restoration of the abandoned coal mining spoils and development of technology to ameliorate waste water pollution discharged from the abandoned coal mining spoils". Authors thank Bong-Hyeong Lee for field sampling and technical assistance in molecular analysis.

\section{LITERATURE CITED}

Adriaensen K, van der Lelie D, van Laere A, Vangronsveld J, Colpaert JV. 2004. A zinc-adapted fungus protects pines from zinc stress. New Phytol 161: 549-555.

Adriaensen K, Vralstad T, Noben JP, Vangronsveld J, Colpaert JV. 2005. Copper-adapted Suillus luteus, a symbiotic solution for pines colonizing Cu mine spoils. Appl Env Microbiol 71: 7279-7284.

Agerer R. 1987-1998. Colour atlas of ectomycorrhizae. Einhorn, Schwawisch-Gmund.

Allen EB, Allen MF, Helm DJ, Trappe JM, Molina R, Rincon E. 1995. Patterns and regulation of mycorrhizal plant and fungal diversity. Plant Soil 170: 47-62.

Allen MF, Allen EB, Zink TA, Harney S, Yoshida LC, Siguenza C, Edwards F, Hinkson C, Rilling M, Bainbridge D, Doljanin C, MacAller R. 1999. Soil microorganisms. In: Ecosystems of disturbed ground, Ecosystems of the world (Walker LR, ed), Elsevier, Amsterdam, pp 521-544.

Bergero R, Perotto S, Girlanda M, Vidano G, Luppi AM. 2000. Ericoid mycorrhizal fungi are common root associates of a Medi- terranean ectomycorrhizal plant (Quercus ilex). Mol Ecol 9: 16391649.

Bruns TD. 1995. Thoughts on the processes that maintain local species diversity of ectomycorrhizal fungi. Plant Soil 170: 63-73.

Colpaert JV, Van LA, Van AJA. 1996. Carbon and nitrogen allocation in ectomycorrhizal and non-mycorrhizal Pinus sylvestris L. seedlings. Tree Physiol 16: 787-793.

Connell JH, Slatyer RO. 1977. Mechanisms of succession in natural communities and their role in community stability and organization. Am Nat 111: 1119-1124.

Dobson AP, Bradshaw AD, Baker AJM. 1997. Hopes for the future: restoration ecology and conservation biology. Science 277 : 515-522

Egger KN. 1995. Molecular analysis of ectomycorrhizal fungal communities. Can J Bot 73: S1415-S1422.

Gardes M, Bruns TD. 1993. ITS primers with enhanced specificity for basidiomycetes--application to the identification of mycorrhizae and rusts. Mol Ecol 2: 113-118.

Gardes M, Bruns TD. 1996. Community structure of ectomycorrhizal fungi in a Pinus muricata forest: Above- and below-ground views. Can J Bot 74: 1572-1583.

Goodman DM, Durall DM, Trofymow JA, Berch SM. 1996-2000. Concise descriptions of North American ectomycorrhizae. Mycologue Publications, Victoria, $\mathrm{BC}$.

Horton TR, Bruns TD. 2001. The molecular revolution in ectomycorrhizal ecology:peeking into the black-box. Mol Ecol 10: 1855-1871.

Jonsson L, Dahlberg A, Nilsson MC, Zackrisson O, Kren O. 1999a. Ectomycorhizal fungal communities in late-successional Swedish boreal forests, and the composition following wildfire. Mol Ecol 8: 205-215.

Jonsson T, Kokalj S, Finlay R, Erland S. 1999b. Ectomycorrhizal community structure in a limed spruce forest. Mycol Res 103: 501-508.

Keizer PJ, Arnolds E. 1994. Succession of ectomycorrhizal fungi in roadside verges planted with common oak (Quercus robur L.) in Drenthe, the Netherlands. Mycorrhiza 4: 147-159.

Malajczuk N, Riddell P, Brundrett M. 1994. Role of ectomycorrhizal fungi in minesite reclamation. In: Mycorrhizae and Plant Health (Pfleger FL, Linderman FG, eds), APS Press, St. Paul, MN, pp 83-100.

Marx DH, Ruehle JL, Kenney DS, Cordell CE, Riffle JW, Molina RJ, Pawuk WH, Navratil S, Tinus RW, Goodwin OC. 1982. Commercial vegetative inoculum of Pisolithus tinctorius and inoculation techniques for development of ectomycorrhizae on container grown tree seedlings. Forest Sci 28: 373-400.

Molina R, Trappe JM. 1982. Patterns of ectomycorrhizal host speci- 
ficity and potential among pacific northwest USA conifers and fungi. Forest Sci 28: 423-458.

Pfleger FL, Stewart EL, Noyd RK. 1994. Role of VAM fungi in mine-land reclamation. APS Press, St. Paul, MN.

Ruehle JL, Marx DH. 1979. Fiber food fuel and fungal symbionts. Science 206: 4417.

Saitou N, Nei M. 1987. The neighbor-joining method: a new method for reconstructing phylogenetic tree. Mol Biol Evol 4: 406-425.

Sakakibara SM, Jones MD, Gillespie M, Hagerman SM, Forrest ME, Simard SW, Durall DM. 2002. A comparison of ectomycorrhiza identification based on morphotyping and PCR-RFLP analysis. Mycol Res 106: 868-878.

Smith SE, Read DJ. 1997. Mycorrhizal symbiosis, 2nd ed. Academic Press, London.

Thompson JD, Higgins DG, Gibson TJ. 1994. CLUSTAL X: Improving the sensitivity of multiple sequence alignment though sequence weighting, position-specific gap penalties and weight matrix choice. Nucleic Acid Res 26: 179-182.

Van Andel J, Bakker JP, Grootjans AP. 1993. Mechanisms of vegetation succession: A review of concepts and perspectives. Acta Botanica Neerlandica 42: 413-433. van der Heijden EW, de VFW, Kuyper TW. 1999. Mycorrhizal associations of Salix repens L. communities in succession of dune ecosystems. I. Above-ground and below-ground views of ectomycorrhizal fungi in relation to soil chemistry. Can J Bot 77 : 1821-1832.

Villarreal-Ruiz L, Anderson IC, Alexander IJ. 2004. Interaction between an isolate from the Hymenoscyphus ericae aggregate and roots of Pinus and Vaccinium. New Phytol 164: 183-192.

Villeneuve N, Le Tacon F, Bouchard D. 1991. Survival of inoculated Laccaria bicolor in competition with native ectomycorrhizal fungi and effects on the growth of outplanted Douglas-fir seedlings. Plant Soil 135: 95-108.

Wright RA, Muller-Dombois D. 1988. Relationships among shrub population structure, species associations, seedling root form and early volcanic succession, Hawaii. In: Plant form and vegetation structure (Werger MJA, v. d. Aart PJM, During HJ, and Verhoeven JTA, eds). SPB Academic, The Hague, pp. 87-104.

Zedler JB, Callaway JC. 1999. Tracking wetland restoration: Do mitigation sites follow desired trajectories? Restor Ecol 7: 6973.

(Received April 1, 2006; Accepted April 20, 2006) 